\title{
イランの教科書にみられる政治的権威の構造
}

\section{The Structure of Political Authority as Expressed in Post-Revolutionary Iranian Textbooks}

桜井啓子

SAKURAI Keiko

\section{はじめに}

イランの学校教科書恃革命前も革命後も両体制の政治的梅威の伝達媒体となって (1) 特に革命後の教科書では，旧体制の権威の剝奪とイスラム共和国を支える新しい権威 の確立が明確な目標として呈示されている。本稿は，革命後の政権が归体制の権威を否 定したらえで，新たに構築しようとしている政治的権威の構造を主に社会科や道徳の教 科書から抽出しようとするものである。分析にあたっては，政治的権威の源泉，指導者 の属性，政治的権威に対する服従の形態，共同体としての国家やウンマのイメージなど に焦点を当てることになるであろら。

ところで，教科書を政治的権威の伝達媒体としてみた場合にどのような特徴があるの かについて簡単に触れて括きたい。教科書とは国家が教育教材として学校での使用を義 務づけたものである。特に，国定教科書は，国家が自らの判断によって記述事項の取捨 選択を抏こなったものであり，国家の自己表現の一形態とみなすことができよう。

もちろん教科書の内容がそのまま学習者に受け入れられ，記憶されるわけではない。 だがそれにもかかわらず次のような理由によってイランに和ける教科書の影響を無視す ることはできない。第一に, 補助教材や学習雑誌, 塾などが少ないイランでは, 学習に 占める教科書の位置は大きい。第二に，イランでは暗記が最も一般的な学習方法であ (3)

る。学生はより高い学歴を求めて, 試験のためにひたすら教科書を暗記する。第三に, 教育行政はきわめて中央集権的で，学校現場での統制が徹底しているイランでは，教科 書の内容に異を晿える者に対して制裁が加えられる。

このように教科書の影響が相対的に大きい社会では，支配者のイメージや国家や民族 といった抽象的な概念の理解において教科書が人々の思考に与える影響もまた大きいと 仮定できるであろう。そして革命後のイランは，教科書の持つこのような性格を最大限

* 学習院大学東洋文化研究所助手

Research Associate, Research Institute for Oriental Cultures, Gakushuin University 
に利用しようとしている格好の事例であろう。革命によってシャーから国家権力を奪取 した革命政権は, その権力を有効に機能させるためには自らを「権威ある」存在として 国民に呈示し，国民の支持を獲得しなければならない。革命後の教科書に頻出する政治 的記述はそのための一つの手段に汭ならない。もちろん教科書に描かれた体制の姿は， 現実の政治構造やそれを支えている権力構造とは異なったものである。けれども，我々 はそこに描かれた政治的権威やその権威に対して要求されている服従の在り方から，そ の体制が何によって自己の権威を説明し，それをどのようなかたちにおいて確立しょら としているのかを知ることができる。

\section{I. 旧体制の権威の剝奪}

革命後すでに10年以上の歳月を経た現在もなお，教科書の随所で旧体制の権威を失墜 させるための努力がなされている。これらの記述は, シャ一時代を記憶に留めない世代 にシャー体制の不正や搾取の状況を語り継ぐことによって，現在でもなお巷で耳にする ことのできる「シャー時代のほうが良かった」といら大人達の言葉を牽制し, 王政に対 する郷愁との決別を促そうとするものとい克よう。

旧体制の批判の仕方を大別すると次のようにならう。第一はシャ一個人の資質を問ら ものであり，第二はシャ一の政策への批判である。第三はパフラヴィー体制やパフラヴ ィー時代全般にわたる批判をつうじて, 王政の不当性を訴光る方法である。第一の事例 には次のようなものがある。

「彼（パウラヴィー王朝初代国王レザー・シャー）は，コサック将校の一人で, 粗暴 であったためにごろつきのレザー・ハーンとして知られていた。彼は読み書きがで きず，政治や統治に関して全く無知であった」(社会小 $5 \mathrm{p} .192)$

第二の批判は外国への従属に向けられたものが多い。

「レザー・ハーンは外国人に対して従順であったが，国民に対しては理不尽なことを 要求し，無慈悲に振る舞った。」(社会小 $5 \mathrm{p} .217$ )

「レザー・ハーンは外国の文化をイスラムと我が民族の文化の代替物にしょうとした。 そしてかなり成功させた。」(社会小 $5 \mathrm{p} .195)$

「彼（レザー・ハーン）はイランを経済的に著しく外国に従属させた。」(社会小 $5 \mathrm{p} .195)$

これ以外にも外国を直接に批判したものがある。例觉ば，

「悪魔（țāghūt）の時代には我々に真の独立がなかった。外国人が我々の国を干渉

し，我々人民の資金や富を略奪していた。彼らは我々の王や首相や大臣を決定して

いた。」(社会小 5 p. 223-224)

シャーの対イスラム政策も厳しい批判の対象となっている。 
「……スクや宗教集会を規制した。彼はイスラムの力を非常に恐れていたために， できるかぎりイスラムとルーハーニーヤト（rūhāniyat）を弱体化させようとし た。」(社会小 5 p.195)

「(レザー・ハーンは) 自由を完全に踏みにじり, 理不尽なことをいい, 宗教の教え に反する支配をした。」(社会小 5 p.195)

第三は，パフラヴィー体制に対する評価である。

「イランのムスリム人民が王政下で見たものは，圧制と暴力と好色と腐敗と贅沢だけ だった。」(社会小 5 p. 229)

パフウヴィー時代の富の不平等な分配も批判の対象になっている。

「(王族は）この宮殿や富のすべてを力づくで手に入れた。彼ら（王族）は自分の宮 殿を繁栄させるためにイランを破壊した。」(社会小 3 p. 57)

「過去にイラン人民を支配した王の多くは圧制者であり，略奪者であった」（社会小 3 pp.57-58) これはパフラヴィーを含む歴史上の王たちへの批判であり，これによっ て王政そのものを否定しようとしている。これらの批判が目指しているのは, シャ 一や王政がもっていたあらゆる肯定的なイメージを完全に崩壊させ, 王の権威が復 活する余地を残さないことである。そのために主観的な表現による批判が目立ち， シャー時代のいかなる政策も客観的な評価の対象とはなっていない。

\section{II. 新しい権威の構築 : ヴェラーヤテ・ファギーフ}

新政権は, 革命に至る過程で革命勢力が全面的に依存してきたホメイニーの権威を維 持するとともに，新政権の標傍する「イスラム法学者による統治(ヴェラーヤテ・ファ ギーフ／velāyat-e faqif)」体制の確立と維持といら課題を負った。教科書も革命後に 大幅に改訂され，理想としての「イスラム社会」の建設に向けて，国民が何を信じ，何 をなすべきかを説く指導書となった。教科書が理想とする「イスラム社会」とは，

「……スラム法に基づいて法が施行され，人々がイスラムの道徳と教育を身に付け ている社会である。イスラム社会に到達するための第一歩がイスラム共和国政府の 樹立である。」(社会小 5 p.231)

この理想に向けて「イスラム法学者による統治」の必要性が説かれることになる。教 科書を引用しながらその内容を検討していくことにする。

(1) 権力の源泉特よび権力の依託

イスラム社会では唯一絶対の神のみが人間を支配する権利を有するという。それは次 のような根拠による。

「支配（tasalloț） と所有権（mālekiyat）の概念の間には明白な関係がある。何か 
を所有した場合に支配が発生する。そして支配が発生すると, 命令も存在すること が可能となる。つまり何かに対して命令できるのは，そのものの所有者だけである。 ……ウえに支配権（hākemiyat）は神のものである。なぜならば神は人間の所有者 であるのみならず，人間の創造主であるからだ……（社会高4 p.55）

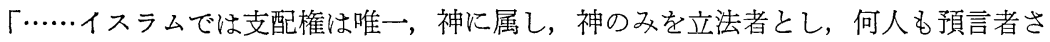
えも立法者の権利を持たない.......。 社会高 4 p. 56)

では神のみが人間に対する支配権を有するときに，なぜイスラム法学者が統治に携わ るのことができるのであろらか。次の文章は神が統治を預言者とイマーム，さらにはイ スラム法学者に依託したことを述べている。

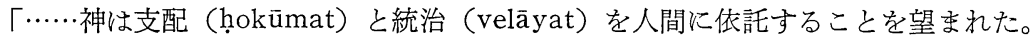
もちろんあらゆる人間に統治を依託するのではない。そらではなく人間の支配 (hokūmat) と指導 (hedāyat) といら仕事を預言者とイマームに, その後は神学 者 (‘ālemān-e dinī) とイスラム法学者 (faqihān-e dinī) に依託したのである。」 （社会高 4 p. 59)

また次のようにも表現されている。

「12代イマームの不在中は, 彼和よび彼以前のイマームらの指導 (rāhnamāyi) と命 令 (farmān) により, イスラム共同体の統治（velāyat）と指導（rahbarī）は「公 正かつ聡明なイスラム法学者（faqif)」の責任となった。」(宗教小 $5 \mathrm{p} .102$ )

これらを言い換えるならば，教科書が展開するイスラムの統治論では人間の創造主で ある神だけが人間を支配する権利を持つ。だが，神は自身の支配権の一部すなわち，統 治と保護を特定の人間に依託した。この特定の人間とは預言者とイマームそしてファギ ーフである。神がこの「指導」を特定の人間にどのように依託したのかについては, 「紹介」であるとか「命令」といった表現が用いられている。しかし，どのようなかた ちにせよ権力の源泉を神に求めるイスラムの統治論は，その神聖なる権力を神から依託 されたとされている預言者, イマーム, イスラム法学者の権力をも神聖化する。

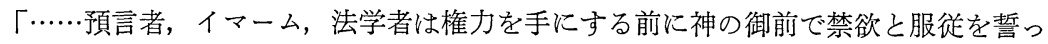
た。つまり，彼らははじめに肉体和よび内面を浄化し，あらゆる腐敗を自己から追 放し，その後に権力を取得している。彼らは権力を不合理や詐欺や欺瞒から手に入 れたのではなかった。彼らの権力は神が彼らに依託したものであり，社会もそれを 受け入れた。…ゆえにこのような人が権力に就いた場合には決して腐敗しない。」 （社会高 4 p.15）

（2）イスラム社会に打ける指導：ヴェラーヤト

指導はイスラムの統治論の中心的な概念の一つである。統治 (velāyat) あるいは指 
導（rahbari） といら言葉で表現される指導は，どのような時代にあってもイスラム共 同体にとっては不可欠のものであるという。

「イスラムへの信仰が統治 (hokūmat) および社会関係や社会行動の基礎にある我及 の社会では，常にある者（たち）がイスラムを人々に紹介し，社会をイスラムの教 義から逸脱しないように守り，人々を幸福へと導かなければならない。これは指導 者の責務である。」(社会小 $5 \mathrm{pp} .236$-237)

12代イマームの不在中, この指導の責務を神から依託され, 統治 (velāyat) の任務 につくのが法学者である。

「イスラム社会の指導者は，指導の資格を人民から得たのではなく，それを天性の価 值として自己のらちに内在させているのである。人民の忠誠や受諾は彼の指導をよ り一層成功させるための条件にすぎない。」(社会高 2 p.42)

「指導者は指導を人民から手に入れたわけではない。彼にとって重要なものは宗教原 理であり，神の命令を遵守することである。指導者は神への服従と神の戒律の説明 にのみ専心する。」(社会高 $2 \mathrm{p} .43$ )

このような指導者への服従が人民に解放をもたらすといら。

「このような指導を受諾することでムスリムは外国人の圧制や略奪者から解放され， 勝利する。我々の時代に指導者を受け入れたことでイランの抑圧された人々は悪魔 の圧制から救済されたと同様に，この指導は世界のムスリムをも抑圧の軛から解放 することになるであろら。」(宗教小 5 p.102)

\section{III. 指導者の属性}

現在のイラン・イスラム共和国憲法第109条では指導者および指導評議会 (shourā-ye rahbari）のメンバーの条件について次のように定めている。

「1，イスラム法学のさまざまな問題について教令を出すために必要な学問的能力。

2 ，イスラム共同体の指導に必要な正義と宗教心。3，指導に必要な正しい政治社 会的な洞察，政策，勇気，管理能力，強さ。上記の条件を有するものが多数の場合 は，イスラム法および政治的洞察においてより優れているものを優先する。」(社会中 3 (1369) p. 103)

これは憲法の拔粋であるが，これ以外にも，指導者の条件に関する説明を散見するこ とができる。

「イスラム社会の指導者はイスラム学者（eslām shenās）でなければならない。指導 者は博学かつ公正でなければならない。指導者はムスリムの手本であり，万事にお いてイスラムの指示と教えに従ら。指導者は常にすべての社会問題に対して，イス 
ラムの教義に基づいて正しい解決方法を示せるよう自分の時代状況を熟知していな ければならない。同様に指導者は国を運営するための十分な能力と政策を持ってい なければならない。」(社会小 $5 \mathrm{pp}$. 237-238)

「イスラム社会の指導者は，イスラム学者でなければならない。」より具体的には

「イスラム社会の指導者に必要な第一条件は，ファギーフであり，モジュタヘドで あること。」(社会中 3 (1369) p.17) となっている。 そして，このファギーフとモジュタへドは，

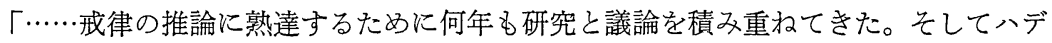
ィースとコーランの全節に完壁に精通している。ハディースとコーランの理解のた めには様々な学問が必要である。法学者はこれらすべての学問を完全に習得した。」 (宗教中 1 p. 148)

このような専門家としての権威以外に要求されているのが「……ららる方法で圧制 と戦う」(社会小 5 p. 238) といら態度である。

また，イスラム共同体の指導を担ら法学者を含むルーハーニーヤトがどの社会階層に 属するのかについても言及されている。

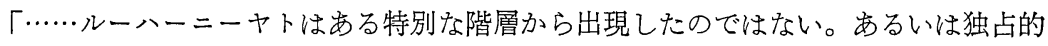
にある特定の階層や社会集団から出てきたわけでもない。精神指導者たら（rūhāniyūn）の中には都市出身者も農村出身者も拈り，多くは貧しい家庭に属している が中流の者もいる。わずかながら金持ちもいる。」(社会高 2 p.76)

だがここで述べられているのはルーハーニーヤトの出身階層に過ぎず，出自の多様性 が国民の多様な利害を公平に代表することの保障にはならない。たとえ彼らの出自が多 様であったとしても, 彼らは神学校での長い教育期間をつうじて師弟関係に基づく特殊 な集団を形成している。特に，革命後はイスラム法学者であることが指導者になるため の前提条件とされているために，その資格を授与する唯一の教育機関である神学校は政 治的な指導者の育成という新たな役割を得た。神学校やモスクを拠点に政治的実権を掌 握したウラマーは，政治権力の維持，拡大という明確な利害を有する集団となった。

\section{IV. 服従の形態}

（1）モジュタへド（模擬される者）とモガッレド（模擬する者）の関係

「イスラム社会では人及はモジュタード (mojtahed) かあるいはモガレッド (moqal led）のいずれかのグループに属する。」(社会高 $2 \mathrm{pp} .44-45$ )

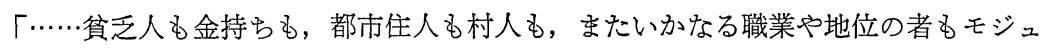
タへドでない者はモガレッドとならなければならない。一国の大統領さえも，モジ 
ヤタードでなければ自分のマルジャエ・タグリードに従わなければならない。」社会 高 2 p.45)

イスラム法学者はイスラムの法や戒律を解釈し推論を下せるよう研鑽を重ねた学者で ある。教科書は専門家としてのイスラム法学者の権威を次のように説明する。

「宗教の真の戒律や法を知るためには誰に問い合わさなければならないか。……宗教 法の推論や知識もまた，との他の技術と同様に熟達と専門知識が必要である。宗教 戒律の推論の専門家がまさにくファギーフとモジュタヘド》である。我々は宗教の 戒律やイスラム法を知るためには彼に問い合わせなければならない。」(宗教中 1 pp. 147 $-148)$

ここでは，イスラム法学者の権威が，医師などの専門家が持つ権威と同質のものとし て説明されている。

ところでイスラム革命によってイスラムの支配は, 宗教の領域のみならず政治や社会 関係を含む人間のあらゆる営みに及ぶようになった。つまり，イスラムは宗教のみなら ず, 政治, 経済, 社会のあらゆる問題に対処することのできる唯一絶対の原理となった のである。そのために，ここに述べられているモジュタへドとモガッレドの関係もまた あらゆる領域に及ぶことを意味する。特に政治の領域に执いてこの関係は次のように説 明される。

「人々は神と預言者と来世への信仰によって神を自分の保護者（vali）とし，神への

服従を義務とみなしている。その結果，イスラムの戒律の説明者であり診断者であ るマルジャエ・タグリードにも服従してきたのである。」(社会高 2 p.48)

教科書が理想とする統治形態はモジュタヘドとモガッレドの間に存在する模擬される 者と模擬する者の関係が，社会のあらゆる領域にまで及ぶことである。さらにイスラム 法学者はその資質ゆえに神から指導を委补られたという解釈により，論理的には無限の 権力を有することになろう。

(2) 殉教

「殉教とは何て美しく意味深きものであろう！」(宗教中 1 p.116)これは教科書の一節で ある。殉教は革命後の教科書の中で最も目を引く言葉である。いかなる理由があるにせ よこの死を意味する言葉が，なぜ，かくも頻繁に甘美なものであるかのよらに使われる のか。革命とそれに続くイラン・イラク戦争に祘いて死が日常化しつつあったイランで 死がどのよらに教えられているのかは，権威に対する究極の服従形態として注目に值す る。

殉教とは，イスラム社会に执いて最も価値ある社会行為とされている献身（ișār）の 最上の形態であるという。（社会小 5 p. 265）殉教はある宗教真理への信仰に根ざしていると 
いう。その真理とは

$\lceil … . .$. 殺されることで彼が得るものは，彼が与光たものより価值のある永遠なもので 西る。捧げるのは，限りあるこの世の生活であり，手に入れるものは神の傍らでの

永遠の命と神の喜びである。」(社会高 $2 \mathrm{p} .115)$

このように殉教者は自分の命を神のために進んで捧げる優れた人物として描かれてい る。では，殉教はイスラム社会にとってどのような価值があるのであろらか。殉教者と はイスラム社会の存続を脅かす敵との戦いに打いて命を落とした者である。専制を倒し イラン革命を勝利に導いたのは，彼らの力であり「この自由と勝利は殉教者の贈り物で ある。」(国語小 3 p. 157)

「殉教者はみな天国へと急ぐ。残してきた者にも神の慈悲を約束する。そして彼らに 聖戦の続行を呼びかける。」(国語小 3 p.157)

殉教はイスラム社会を守る最強の武器とみなされている。

「人々が殉教を死や消隇としてではなく, 自己の発展のための偉大な一歩として, 輝 かしい生と永遠の魂への歩みとして受け入れるならば，所持するすべての武器で敵 を無力にするであろう。殉教は信じる者が他のあらゆる武器を無能にすることので きる武器である。」(社会高 2 p. 115)

宗教と政治の一致を主張する現体制下のイランにおいて，イスラムを守るための死は， 同時に現政権を守るための死でもある。殉教は殉国であり，殉国は殉教となる。このよ らな思想は，次のような言葉となって教科書にあらわれることになる。

「私の国の独立と栄光を守るために，喜んで殉教します。……私は名誉ある死が無意

味な生よりも優れていると信じています。いかなる理由があっても捕虜にはなりま せん。誇りをもって戦場に行きます。私は戦います。そして殉教と名誉の二つを選 び取ります。」(国語小 4 pp. 194-195)

これまで民衆の宗教世界のなかで親しまれ，語りつがれてきた三代イマーム・ホセイ ンの殉教が，現実のものとして自分達に要求されるようになった。革命によって解き放 された人々のエネルギーが殉教といら方向を与兄られ, 献身競争へと駆り立てられたの である。

\section{V. 共同体としての国家とウンマのイメージ}

このような統治形態を理想とするイスラム社会はどのような国家を形成することにな るのであろらか。教科書が描く国家のイメージはどのよらなものであろうか。いくつか の事例を引用してみることにする。

「イランの各州に住む人々は経済抒よび農業活動に拈いて，あるいは社会習慣に扔い 
て違いはあるが，皆，まるで一つの家族の成員のように相並び，一致団結して一つ の家に暮らしている。この大きな家の名はイラン, 家族の名はイラン国民 (mellate İrān) である。イラン人民は，共通の歴史を持っている。この人民は何世紀もの 間, 共に王や権力者たちの抑圧に苦しんできた。として彼らに対して蜂起し, 自分 達の宗教と習慣と国土を守った。」(社会小 4 pp. 170-171)

また，国民の間に利害の一致と連帯が存在していることが次のように強調されている。 「イラン・イスラム革命は過去の軛からの解放と共通の目標を目指すイラン国民 (mellat-e İrān) の団結の印である。農民, 都市住人, トルコ, トルコマン, ク ルド, ロル, バルーチー, ファールス, アラブから成る国民は, 神を信じ, イラン でイスラムにもとづく人間的な生活を求めている。イラン国民は共通の憲法, 国旗, 国歌と暦を持っている。」(社会小 $4 \mathrm{p} .171$ )

このようにイラン国家への帰属意識が啓発される一方で, 現政権はウンマと呼ばれる $\lceil …$ 人種, 血縁, 領土, 言語に基づく社会ではなく, 信念と信仰をもとに形成される 社会」(社会中 $1 \mathrm{p}$. 57) をも理想に掲げ，この共同体の共通語であるアラビア語の学習を義 務づけている。ではこのイスラム共同体とは何か。

「私達はムスリムであり, 私達の宗教はイスラムである。世界の各地に住むムスリム は他のムスリムと信念と目標を共有している。イスラム共同体は世界の全ムスリム によって構成される社会である。世界の全ムスリムは, 白人も黒人も, イラン人も卜 ルコ人もアラブ人もアフリカ人もアジア人も, またヨーロッパやアメリカやソビエ トのムスリスでさえもイスラム共同体の一部であり, 皆互いに兄弟であり, 対等で ある。……我々イランのムスリム人民はイスラム共同体の一部であり, 自分と世界 の他のムスリムとの連帯を一層強化するために努力している。」(社会小 4 pp. 181-182) このように理想として描かれたウンマも現実には次のような問題を抱えている。

「残念なことに現在，イスラム諸国は互いに連合していない。政府の一部は，イスラ ム諸国との関係よりもイスラムの敵と連合したり，友好関係をもっている。根本的 な原因は, 概してこれらの政府が自国のムスリム大衆の真の代表ではなく, 人々を 統治するに相応しくないからである。」(社会中 1 pp. 57-58)

そして, このよらな現状を遺憾とし, 将来にむけて次のような決意を表明している。

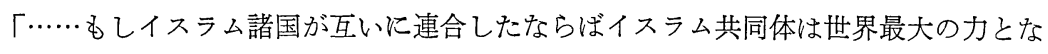
り，ムスリムは外国人の支配と現在の困難から解放されるであろら。……我々の憲 法によると, イスラム共和国の確固たる義務の一つは, イスラムの発展と神の法の 支配を世界に広げるよう努力することである。」(社会中 1 pp.57-58)

イラン国民として人々のアイデンティティーを国境内に凝集しょうとする力とイスラ 
ム共同体の一員といら空間的制約のない共同体へむかってアイデンティティーを拡散し ようとする理想との間には緊張が存在する。またイランは, イスラムへの信仰を体制の 根幹としているものの，わずかながらも宗教的小数派を抱光ている。彼らはン゙ロアスタ 一教徒, アルメニア教会及びネストリウス派のキリスト教徒, 二ダヤ教徒, 極く小数の プロテスタントやローマ・カトリックである。彼らの宗教的な自由は憲法に执いて保障 されている。

学校では彼らに対して『神の宗教と道徳教育，特別な宗教的少数派（ユダヤ教徒，ゾ ロアスター教徒，キリスト教徒)』と題する教科書を用意している。現体制は一方で信 仰の自由を保障しながらも，彼らをイスラム体制に統合するために神への帰依といらイ スラムと共通する主題を中心に据えながら神が人間を導くために必ず預言者を送ること を強調している。この文章はムスリム括よび非ムスリムの両方の宗教の教科書に揭載さ れた文章である。

「人間を創造された慈悲梁き神が，この障害の多い旅路に人間を綱領や指導者や案内 人なしに放置することなどありえようか。いいや。断じてそのようなことはない。

神はこの複雑で障害の多い旅路に人間を放置することなく, 人間のために案内人 （rāhnamā) と指導者（rahbar）を送られた。」(宗教 (少数派用) 中 $1 \mathrm{p} .56$ )

ここでも，神と人間の間に預言者，案内人，指導者と呼ばれる者を介在させ，そのよ らな状態が常に存在することを示唆している。預言者という表現以外飞案内人, 指導者 といら表現を用いているのは, ファギーフの存在を意識してのことである。非ムスリム に対してるまたムスリムと同様にイスラム法学者による支配を受け入れるための下地が 教育されているのである。

\section{むすひ}

これまで教科書の記述を引用しながら，革命後の体制が理想としている政治的権威の 特徵を論じてきた。最後にこれらの特徵をるら一度確認することによって全体像を描い てみることにしたい。

まず第一に教科書が展開しているイスラムの統治論の最も重要な特徴は, あらゆる権 力と権威の源泉を神に求めていることである。このような解粕が前提にしているるのは 人々の神への信仰である。人々は神の権威を認めるがゆえに, 神から発せられたとされ るめらゆる命令に自発的に服従しょうとするのである, ただし, 神の権威が広く認めら れている社会に括いて一部の者が神の権威を認めないと表明することは困難である。な ぜならば，神の権威を否定する者に対して実際には精神的，物理的な制裁が加えられる からである。神の権威を統治の基礎とする社会では, 神の権威を認めるよう個人に対し 
て社会的な強制力が働くことになる。しかし体制が政治的権威として存続するためには， 物理的な強制による脅迫は不十分であるばかりか，かえって反発を招くことにもなる。 教科書は学校教育の場に存在する強制力を利用して, 神の権威への自発的な服従を教育 する。

第二の特徵は，神と人間の間に神の代理人が介在し，この代理人が人間の統治に携わ るとしている点である。神の代理人として位置づけられる法学者の権威はいくつかの拠 り所をるっている。第一は専門家としての権威である。これは長期にわたる専門教育の 結果, イスラム法学および関連の諸学問に精通しているところから引き出されたもので ある。これは，医者など他の専門家の持つ権威々同質のものと説明されている。第二は 法学者は, 預言者やイマームの不在中, イスラム社会の指導を神から依託されたといら 解釈から引き出される権威である。法学者の判断はあらゆる誤謬から解放された絶対的 なものとして説明される所以である。第三はイラン史上初めてイスラム法学者による統 治を実現させたホメイニーのもつカリスマ性がもたらす権威であるう。革命を成就させ たことによってホメイニーが個人的に獲得した権威がイスラム共和国憲法のなかで彼の 後継者にも引き継がれることが成文化されたのである。

このようにしてイスラム法学者は, 専門家としての権威を維持するために最高水準の 問題解決能力を国民に示さなければならない。として尃門家としての判断は他の二つの 権威の力を借りることによって神聖化され，あらゆる批判を回避することができる。

第三の特徴は, 統治者之被統治者との関係である。統治者であるイスラム法学者はそ の支配権を神から依託されたとすることで, 䜋謬から解放された完全な指導者となる。 そしてイスラム法学者と国民との関係は模擬される者と模擬する者の関係として説明さ れる。言い換えれば国民は権力者に対して服従を強要される存在ではなく, 指導者に自 発的に追随する存在として描かれているのである。この法学者による指導は人々が神と 直接に対話をする可能性を狭め, 統治に限らず社会の様々なレベルにおいてウラマーの 指導を拡大させている。

第四の特徵は，国家の最高指導者がもつ「指導」といら地位の特殊性である。教科書 が理想として描く最高指導者は, 権力の極度の集中により専断的な支配を行ら独裁者で はない。再び教科書の言葉を借りれば，「ホメイニーは政治を個人と社会をイスラムの 崇高な目的に導くこと」(社会高 $4 \mathrm{pp} .7-8)$ と文なしており，「イスラムにおいては個人の 指導が教育であり，社会の指導が政治である。」(社会高 4 p.9)

また指導の地位にある者の絶対性を繰り返し述べているが，多くは具体的人物像に触 れることなく抽象的に説明している。すでに紹介してきたようにほとんどの場合, 指導 者, 法学者という用語が使用されており, 革命以来この地位にあった故ホメイニーとい 
ら個人や彼の後継者となったハーメネイという個人への忠誠や服従としては表現されて いない。

最後に本稿では正面から扱うことができなかったが，この「イスラム法学者による支 配」といら統治形態がイスラムを規範とする公正な社会の建設とイスラムの道徳観に基 つくく人間形成を目標に揭げている点を指摘しておきたい。シャ一時代に導入された公教 育か欧米の教育技術者に依存し，西洋文化の模擬に偏っていたためにムスリムとしての 誇りとアイデンティティーの喪失をもたらしていたといら歴史的経緯を振り返るならば， 理想の社会像及び人間像を明確に打ち出す革命後の教育はイランがはじめて主体的に取 り組んだ教育計画としても評価されなければならないであらう。

このような教科書に描か水た革命後の政治的権威の構造は, 学習する人々に何をるた らすのであろうか。イラン革命の成功は武器を持たない民衆の革命運動への参加による ところが大きい。民衆の多くがホメイニーを!2代イマーム・マフディーの再臨であるか のように受け留め彼の指導を仰いできた。けれぞも, 革命後に確立された「法学者によ る統治」はイランのシーア派史上類をみないものである。 ラム教徒でありつづけた民衆が培ってきたイスラムとも異なるものである。イランのム スリムは「イスラム法学者による統治」というイスラムの新しい形態に直面している。 教育する側の揭げるこの新しいイスラムと教育される側が日常世界に拉いて培ってきた イスラムとが教育現場で交差していくなかでイランのイスラムの新しい姿が形成されて いくことになろう。

使用した教科書及び引用上の略語（紙面の関係上教科書の引用に限り割註とする）

Ta‘limāt-e Ejtemā‘ì, Sevvom-e Dabestān, 1364 (1985-86) 社会小 3

Ta 'limāt-e Ejtemā' 'í, Chahārom-e Dabestān, 1364 (1985-86) 社会小 4

Ta‘limāt-e Ejtemā’ìi, Panjom-e Dabestān, 1364 (1985-86) 社会小 5

Ta‘limāt-e Ejtemā‘i, Sal-e Avval-e Doure-ye Rāhnamāyi-ye Taḥṣili, 1369 (1990-

91）社会中 1

Ta‘limāt-e Ejtemā‘ì, Sal-e Dovvom-e Doure-ye Rāhnamāyì-ye Taḥ̣ịili, 1369 (1990 -91）社会中 2

Ta‘limāt-e Ejtemā‘í, Sal-e Sevvom-e Doure-ye Rāhnamāyi-ye Taḥșilì, 1369 (1990 -91) 社会中 3 (1369)

Ta‘limāt-e Ejtemā'î, Sal-e Sevvom-e Doure-ve Rāhnamāyi-ye Taḥṣili, 1368 (1989 -90) 社会中 3 (1368)

Dānesh-e Ejtemā'ì, Āmūzesh-e Motavassețe-ye 'Omūmi, Sāl-e Dovvom, 1369 (1990 -1991）社会高 2

Dānesh-e Ejtemā‘ì, Āmūzesh-e Motavassețe-ye 'Omūmi, Sāl-e Chahārom, 1366 
(1987-1988) 社会高 4

Farhang-e Eslāmi va Ta'limmāt-e Dinì, Panjom-e Dabestān, 1364 (1985-86) 宗教 小 5

Farhang-e Eslāmi va Ta'limāt-e Dini, Sal-e Avval-e Doure-ye Rāhnamāyi-ye

Taḥșili, 1362 (1983-1984) 宗教中 1

Farhang-e Eslāmi va Ta'limāt-e Dnini, Sal-e Dovvom-e Doure-ye Rāhnamāyì-ye Taḥ̣ili, 1366 (1987-88) 宗教中 2

Ta'limāt-e Adyān-e Elāhì va Akhlāq, Vizhe-ye Aqalliyathā-ye Mažhabi, 宗教 (小数派用) 中 1

Sal-e Avval-e Doure-ye Rāhnamāyi-ye Taḥṣili, 1368 (1989-1990)

Fārsī, Sevvom-e Dabestān, 1361 (1982-83) 国語小 3

Fārsì, Chahārom-e Dabestān, 1361 (1982-83) 国語小 4

注

（1）革命前後の教科書に含まれている政治的イデオロギーを伝達する用語の量的比較 については, 桜井啓子「イラン・イスラム共和国のイデオロギー：小学校国語教科書 の内容分析」『アジア経済』1987年，第28巻，第3号を参照していただきたい。この 他にも革命後の教科書に触れたものとしては, M.Mobin Shorish, “The Islamic Revolution and Education in Iran," Comparative Education Review, vol.32, no.1, 1988. Jalal Matini, "Negating the Past," Index on Censorship, vol.14, no.5, 1985. Jalāl Khāleqi Moṭlaq, "Ketābhā-ye Darsì dar Jomhūrī-ye Eslāmì-ye İrān," İrān Nāmeh, vol.3, no.1, 1984.などがある。

（2）革命後，Roshd と呼ばれる補助教材が教育省から発行されるよらになった。こ の Roshd には国語 (Roshd-e Adab-e Fārsì), 社会 (Roshd-e 'Olm-e Ejtemā'ī) など各教科の他に，教師用 (Roshd-e Mo‘allem) や青年用 (Roshd-e Nou Javān) などもある。これらは各教科の情報や解説を揭載しているばかりではなく，特集や読 み物を通じて青少年にイスラム道德を教えよらとしたものである。

（3）イランの教育方法が暗記中心であることについては, Issa Khan Sadiq, Modern Persia and Her Educational System, New York; Columbia Univ., 1931, p.102. 津田元一郎「イランに括ける教育の近代化への適応」河野重男・新井郁男編『現代ア ジアの教育課題』アジア経済研究所 1976年 p.120などで指摘されている。

（4）革命後は，反革命的教員のパージが行われるとともに，教師らはイスラムのイデ オロギーを信奉するよう再教育された。Said Amir Arjomand, The Turban for the Crown, New York: Oxford Univ. Press, 1988, p.170

（5）ルーハーニーヤトといら用語は革命後頻繁に使われるようになったもので，「精 神指導者集団」といった意味であろう。モッタへデは, 語源を同じくするルーハーニ イユーンといら用語について革命後ムッラーたちが, 次第に自分達のことをルーハー 
ニイニーンつまり「精神的な事柄についての専門家たち」と呼ぶようになったと述べ ている。Roy Mottahedeh, The Mantle of the Prophet, New York; Simon and Schuster, 1985 p.237

（6）ファギーフとは，イスラム法 (fiqh) を専門とするイスラム法学者のことである。 この「法学者による統治 (ヴェラーヤテ・ファギーフ)」といら概念は, 18世紀以降, シーア派の政治思想において概ね主流となっていたが，その場合のヴェラーヤトは

「後見・監督」であり，統治者に助言をするといら意味であった。それを法学者によ る直接統治に読み変え, 実行したのがホメイニーである。八尾師誠「イスラムと近代 西欧との出会い:イランのシーア派イスラムの場合」森本公誠編『イスラム変転の歴 史』筑摩書房 1985年 p.155参照

（7）「神はこの地位（イスラム共同体の指導）に相応しい人間を人々に紹介する。」 $\lceil … . .$. 預言者は自分の後継にアリーを人民の保護者（vali)，指導者（rahbar）とな るようにムスリムに紹介した。」

「アリーもまた……神の命令と預言者の指示によりハサンを指導者に選び，ムスリム に紹介した。」(下線は筆者) 宗教小 5 p.101-102

（8）一般にペルシア語で指導をラフバリー（rahbari）といらが，特にコーランでは この指導をヴェラーヤト (velāyat) として説明する。ヴェラーヤトとは友情 (dūsti), 援助 (yārì), 監督 (sarparasti), 権力の所有者（șāheb ekhtiyārīi)のような意味で ある。そして現在の意味は監督である。社会 高 2 p.36

（9）ホメイニーの死後, 憲法の一部が改正された。以下は, 改正以前の第109条である。 「指導者及び指導評議会の条件拉よび特質について 1 一教令の発令とマルジャエ・タ グリードとしての仕事に必要な学識と宗教心 2-指導に必要な政治的社会的洞察, 勇気，強さ，管理能力。」社会 中3 (1368) p.103

（10）モジュタへドとは，研鑽の末，その能力がェジュテハードの行使（教義決定およ び立法行為）を許可されるまでに達した者。

ホメイニーが存命中の教科書は次のように説明している。「イスラム社会の指導者に 必要な第一条件は，ファギーフであり，モジュタヘドであり，マルジャエ・タグリー ドとしての資格（sharāyet-e marja“iyat）を有すること。」社会 中3 (1368) p.17 ホメイニーの死後, この最高位のイスラム法学者であることを示すマルジャイーヤト の資格が指導者の条件からはずされた。このことはイスラム法学者と政治的指導者と の両立が必ずしも容易ではないことを示唆している。教科書はイスラム法学の専門家 としても最高位にあり，政治家としても他に追随を許さない優れた人材であることを 理想の指導者として描き続けながらも，ホメイニーの死後の憲法改正は理想と現実と の妥協を求めたものといえよう。

（11）アラビア語学習の義務化について憲法第16条は次のように定めている。「コーラ ン拉よびイスラムの科学や学問はアラビア語であり, かつペルシア文学は完全にそれ と混合してきたので, アラビア語は初等教育から中等教育終了に至るまで全学級, 全 
学科において教授されなければならない。」社会 中 3 (1369) p. 82

(12) Donald N. Wilber, Iran Past and Present, Ninth Edition, New Jersey;

Princeton Univ. Press, 1981, p.162

（13）帚法第13条

「ゾロアスター教徒, ユダヤ教徒及びキリスト教徒のイラン人は唯一の承認された宗 教的少数派であり, 法の範囲内で自分達の宗教儀式を遂行することは自由であり, 自 分達の慣習に従って，私的事柄や宗教教育を行う。」社会 中 3 (1369) p.80

（14）現世にお打る「法学者による統治」の実施はもちろんのことその概念すらもシー ア派の伝統思想からはきわめて逸脱したものである。この「法学者による統治」は法 学者の権威を宗教の領域から政治の領域にまで拡大し, これを正当化したものである が，このような「神権政治」に異を唱党るアーヤトッラも存在し，シーア派世界に掠 いて合意が成立しているわけではない。特に，「法学者による統治」を支持するホメ イニーを中心とする一部の勢力は，権力を完全飞掌握する段階で，これに反対して きたアーヤトッラたちに対して弾圧を加えた。S.A. Arjomand, Turban for the Crown, New York: Oxford University Press, 1988, 参照。

（15） 聖職者の揭げる公式のイスラムと民衆のイスラムとの違いについては，上岡弘二 「イランの民衆のイスラムと社会意識」加納弘勝編『中東の民衆と社会意識』アジア 経済研究所 1991年 pp.43-83 を参照していただきたい。

これに対して Shorish は，次のように述べている。「イスラムは大半のイラン人の宗 教であると同時に政府の革命的プログラムであるので, 政府の公式的な革命的諸価值 （教科書や他のメディアが伝達することになっている諸価值）と家庭や礼拝場や職場 といった他の機関で教えられている諸価値との間に矛盾を見いだすことはない。」M.

Mobin Shorish, "The Islamic Revolution and Education in Iran," Comparative Education Review, vol.32, no.1, p.60 